\title{
MAKALAH \\ KEKERASAN DALAM DUNIA PENDIDIKAN AKIBAT RUNTUHNYA NILAI MORAL
}

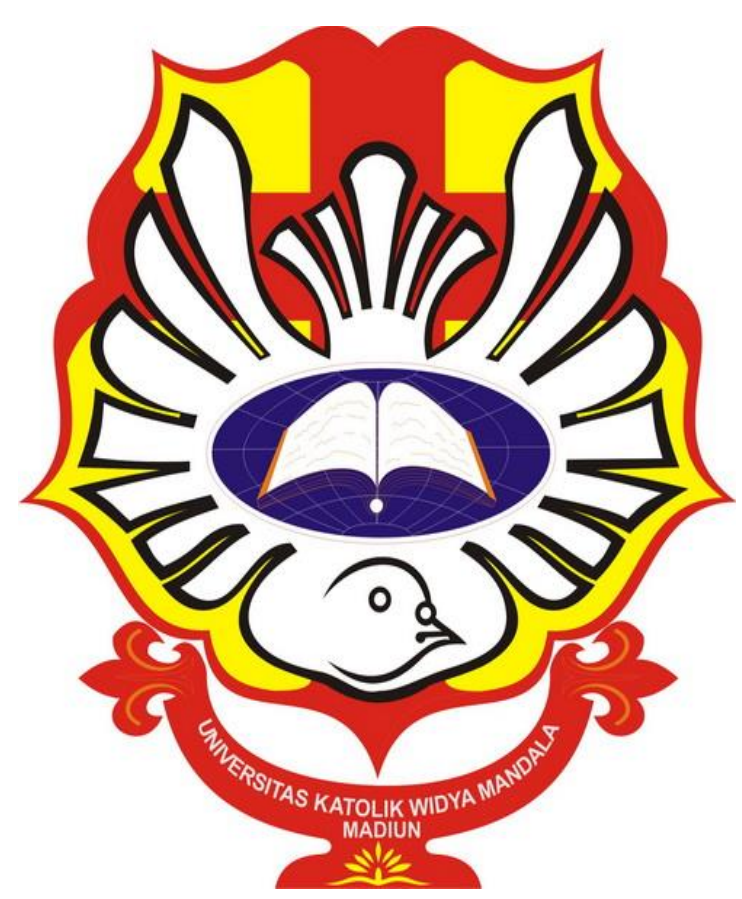

Nama : Adelia Intan Yuriska

$$
\text { NIM : } 32318001
$$

PROGRAM STUDI D-III FARMASI

FAKULTAS MATEMATIKA DAN ILMU PENGETAHUAN ALAM

UNIVERSITAS KATOLIK WIDYA MANDALA MADIUN

Jl Manggis No 15-17 Madiun

Telp (0351) 453328

Fax (0351) 453167, http.//www.widyamandala.ac.id

Email : widyamandala@widyamandala.ac.id 


\begin{abstract}
ABSTRAK
Dewasa ini banyak terjadi kasus yang melanggar nilai moral dan tidakan manusia seperti kasus penganiayaan guru oleh seorang muridnya yang terjadi di SMA Negeri 1 Torjun, Sampang, Madura, Jawa Timur. Peranan guru terhadap masa depan seorang anak sangatlah besar. Guru memberikan didikan ilmu kepada anak yang sangat bermanfaat di kehidupannya mendatang. Betapa pentingnya kita harus bisa menghargai jasa dan pengorbanan para guru. Dari berbagai kasus dalam dunia pendidikan memang membuktikan bahwa kemerosotan nilai moral di kalangan peserta didik sudah mulai terjadi. Keberadaan guru tidak lagi selamanya dipandang sebagai profesi yang terhormat. namun tindakan tersebut juga bisa terjadi karena factor didikan orang tua dan kurangnya refleksi dari hati nurani.
\end{abstract}




\section{PENDAHULUAN}

Moral merupakan suatu peraturan yang sangat penting ditegakkan pada suatu masyarakat karena dapat menjadi suatu rambu-rambu dalam kehidupan serta pelindung bagi lingkungan tersebut. Moral dihasilkan dari perilaku intelektual, emosi, atau hasil berfikir setiap manusia yang pada hakekatnya merupakan aturan dalam kehidupan untuk menghargai dan dapat membedakan tentang benar dan yang salah berlaku dalam suatu masyarakat. Bila orang membicarakan moral seseorang maka yang dibicarakan ialah kebiasaan, tingkah laku atau perbuatan orang atau kelompok masyarakat. Moralisasi dimaksudkan usaha menyampaikan ajaranajaran moral tersebut, sehingga aturan-aturan, tingkah laku dan perbuatan yang telah disepakati oleh seluruh masyarakat untuk dihayati dan dilestarikan oleh anggota masyarakat maupun penerusnya, maka hal-hal yang dianut dan dijadikan aturan tingkah laku tersebut dinamakan nilai moral. Perbuatan manusiawi yang terjadi bisa saja dari beberapa factor nilai moral misalnya fakor hati nurani, secara fenomena dari realitas kehidupan bahwa manusia selalu melakukan pertimbangan-pertimbangan dalam hidupnya. Misalnya manusia memiliki semacam pilihan untuk menegaskan pilihan-pilihan tersebut dan melakukan keputusan yang di pilihnya tersebut. Selain itu tindakan manusia juga menjadi factor bahwa manusia bertindak itu normal (sudah dengan sendirinya). Karena tindakan manusia tidak hanya berkaitan dengan eksistensinya sebagi makhluk hidup, melainkan juga mencetuskan nilai-nilai manusiawi. Perbuatan moral merupakan tindakan manusia sebagai manusia. Manusia adalah ciptaan tuhan yang memiliki akal budi. Perbuatan moral mencetuskan kodrat manusiawi dan sekaligus mulia. Kejahatan itu tidak hanya sekedar berkaitan dengan efek atau akibat buruk dari perbuatan fisik manusia.kejahatan juga bukan sekedar wujud kelemahan manusia karena telah melakukan tindakan-tindakan yang tidak semestinya. Kejahatan moral menyentuh langsung realitas kodrati bahwa kita mempunyai kebebasan. Kita semua bisa membahas secara panjang mengenai kejahatan manusia, tetapi titik tolak yang pasti ialah bahwa manusia memiliki kebebasan dan mampu me refleksi dari hati nurani yang benar, misalnya menggunakan akal budi secara sehat dan jernih, tujuan tindakan harus selalu masuk akal dan terarah kepada kebaikan, mampu bertanggung jawab atas tindakannya, selalu berfikir positif (kebaikan harus dilakukan dan keburukan harus dihindari).

Pancasila sebagai dasar falsafah merupakan moral bangsa yang telah mengikat negara sekaligus mengandung arti telah menjadi sumber tertib negara dan menjadi sumber tertib hukum serta jiwa seluruh kegiatan dalam segala aspek kehidupan negara maupun 
masyarakat. Pancasila merupakan nilai moral, sekaligus mengandung arti sebagai norma. Pancasila sebagai norma terdiri dari lima norma, sebagai mana tercantum dalam lima sila Pancasila yang memiliki unsur bersama, sehingga dapat diterima oleh seluruh rakyat Indonesia. Pancasila sebagai moral mengikat seluruh bangsa Indonesia karena nilai-nilai moral yang terkandung dalam Pancasila yang bersifat universal. Pancasila yang merupakan moral negara sekaligus menjadi moral individu, sebagai moral individu mengatur sikap dan tingkah laku manusia. Pilihan seseorang untuk menjadi guru adalah panggilan jiwa untuk memberikan pengabdian pada sesama manusia yang berkecimpung di dunia pendidikan. Pendidikan merupakan sarana guru di dalam proses pembelajaran untuk mengembangkan potensi kognitif, afektif dan psikomotorik. Menurut UndangUndang Republik Indonesia Nomor 20 Tahun 2003 Sistem Pendidikan Nasional pengertian pendidikan adalah: Usaha sadar dan terencana untuk mewujudkan suasana belajar dan proses pembelajaran agar peserta didik secara aktif mengembangkan potensi dirinya untuk memiliki kekuatan spiritual keagamaan, pengendalian diri, kepribadian, kecerdasan, akhlak mulia, serta keterampilan yang diperlukan dirinya, masyarakat, bangsa dan negara. Guru adalah profesi yang mempersiapkan sumber daya manusia untuk menyongsong pembangunan dalam mengisi kemerdekaan. Menyandang profesi guru adalah manusia yang pantas untuk ditiru dalam kehidupan bermasyarakat khususnya oleh murid. Selamanya guru adalah teladan yang indah bagi dunia pendidikan. Penghargaan terhadap guru dapat diungkapkan ketika ajarannya dapat diteladani dan diterapkan dalam kehidupan sehari-hari, oleh karena itu, guru sering dipandang sebagai sosok yang harus digugu dan ditiru.

Berkaitan dengan hal tersebut guru haruslah berkompeten atau piawai dalam menjalankan tugas dan perannya. Tanggung jawab guru yaitu:

1. Tanggung jawab moral bahwa setiap guru harus mampu menghayati perilaku dan etika yang sesuai dengan moral Pancasila dan mengamalkannya dalam pergaulan sehari-hari.

2. Tanggung jawab dalam pendidikan di sekolah; bahwa setiap guru harus menguasai cara belajar mengajar yang efektif, mampu mengembangkan kurikulum, silabus dan rencana pelaksanan pembelajaran, melaksanakan pembeljaran yang efektif, menjadi model bagi peserta didik, memberikan nasehat, melaksanakan evaluasi hasil belajar, dan mengembangkan peserta didik.

3. Tanggung jawab dalam bidang kemasyarakatan; bahwa setiap guru harus turut serta mensukseskan pembangunan, yang harus kompeten dalam membimbing, mengabdi dan melayani masyarakat. 
4. Tanggungjawab dalam bidang keilmuan; bahwa setiap guru harus turut serta memajukan ilmu, terutama yang menjadi spesifikasinya, dengan melaksanakan penelitian dan pengembangan. Seorang guru menyadari bahwa perlu adanya ketetapan etika profesi guru sebagai pedoman dalam bersikap serta berperilaku yang mencerminkan nilai-nilai moral sebagai pendidik anak bangsa. Ketetapan etika guru yang tercermin dalam kehidupan yang disebut dengan etika profesi guru. Ketika menjalankan tugasnya, seorang guru harus sepenuhnya sadar akan kode etik guru yang merupakan pedoman dalam bersikap serta berperilaku yang menunjukkan nilai-nilai moral sesuai dengan Pancasila serta etika jabatan sebagai guru. Sebagai seorang murid kita harus mempunyai sikap atau rasa tawadlu` terhadap guru kita. Harus bisa menempatkan seorang guru pada tempatnya. Karena guru adalah pahlawan tanpa tanda jasa. Setidaknya kita harus belajar sedikit untuk lebih menghargai guru kita. Guru juga merupakan orang tua kita disekolah. Percuma saja jika seorang murid itu sangat pandai tetapi tidak bisa bersikap sopan terhadap guru kita.

Lalu cara yang baik seorang murid menghormati atau bersikap sopan kepda seorang guru, diantaranya adalah sebagai berikut :

1. Selalu senyum, salam dan sapa ketika bertemu guru

Sikap ini merupakan sikap yang sederhana dan mudah dilakukan, akan tetapi mempunyai manfaat yang sangat banyak.

2. Tidak berjalan didepannya

Maka tidaklah pantas bagi seorang murid berjalan didepan seorang guru. Jika ingin berjalan didepan seorang guru, maka kita harus meminta ijin terlebih dahulu. Itu menunkkan ketawadlu’an seorang murid terhadap guru.

3. Tidak menempati tempat duduk seorang guru

Jika didalam ruang kelas maka tidak sopan pula kita duduk ditempat duduk guru kita. Hal ini kental dengan sikap orang jawa yang sangat menjunjung tinggi untuk tidak duduk ditempat duduk guru.

4. Mentaati perintahnya

Jika diperintah guru harus segera melaksanakannya tanpa harus menunda-nunda apalagi sampai menolaknya. Demikian juga ketika kita dipanggil, juga harus segera memenuhi panggilannya.

5. Menghormati segala sesuatu yang berhubungan dengan guru

Seperti keluarganya, anak-anaknya dan istrinya. Karena itu termasuk bagian dari diri seorang guru.

6. Tidak banya bicara ketika bersamanya 
Bicaralah yang penting saja dan jangan berbicara suatu hal tidak disukai oleh seorang guru.

7. Memperhatikan apa yang dijelaskan oleh guru ketika didalm kelas

Usahakan fokus ketika guru menerangkan dan tidak berbicara sendiri

8. Meminta izin ketika akan melakukan sesuatu

Misalnya bila kita ingin ketoilet, maka hendaknya kita harus meminta izin terlebih dahulu.

Jika guru kita tidak mengizinkan maka terimalah dengan tidak menguirangi rasa hormat kita.

9. Meminta maaf jika berkata atau bertindak salah kepada guru

Segeralah meminta maaf apabila kita melakukan salah kepada guru kita.

10. Berupaya menyenangkan hatinya dengan baik

Buatlah guru kita merasa nyaman ketika didalam kelas maupun dimana saja.

11. Berkatalah dengan lembut

Janganlah berbicara dengan suara yang keras, hingga membuatnya kaget. 


\section{PEMBAHASAN}

\section{Kekerasan Siswa Terhadap Seorang Guru Dalam Dunia Pendidikan Akibat Runtuhnya Nilai Moral}

Lagi-lagi dunia pendidikan nasional berduka. Seorang guru kesenian SMAN 1 Torju, Kabupaten Sampang, Jawa Timur bernama Ahmad Budi Cahyono (Guru Budi), tewas digebuk muridnya. Peristiwa sadis dan tragis ini semakin memilukan ketika diketahui, ternyata guru Budi masih berstatus sebagai tenaga pengajar honorer alias guru tidak tetap. Guru Budi merupakan sosok pengajar multitalenta. Dia hanya menerima gaji di bawah upah minimum kabupaten (UMK) Sampang, yaitu sekitar Rp 500.000 hingga Rp 600.000. Terlepas dari kisah tragis tewasnya Guru Budi, kasus ini menjadi momentum bagi lembaga pendidikan nasional dan seluruh instrumennya untuk melakukan evaluasi secara menyeluruh. Ada apa dengan dunia pendidikan kita?. Krisis moral siswa semakin mengancam bangsa ini. Anda boleh percaya, boleh juga tidak.

Tindak kenakalan siswa yang cenderung mengarah kepada perbuatan sadis sudah menjadi fenomena di negeri ini. Nafsu dan emosi sesaat untuk mengejar pengakuan identitas diri, telah merusak akal sehat pelajar. Mengapa generasi sekolah mudah sekali berperilaku sadis dan keji? Kuncinya ada di sistem pengajaran dan pendidikan serta harmonisasi kehidupan siswa dalam keluarga. Ketika nilai-nilai agama tidak lagi ampuh mengarahkan moral manusia, maka tak ada lagi rasa saling sayang menyayangi antarsesama. Ketika hukum bisa dibeli, maka kehidupan manusia menjadi ajang transaksi. Ketika teknologi salah diterapkan, maka peradaban manusia menjadi rusak. Ketika kekayaan materi menjadi ukuran status sosial, maka manusia akan memiliki sifat rakus dan serakah. Sekolah beserta seluruh instrumennya, mungkin sedikit sekali memberi pengajaran dan pemahaman kepada para siswa tentang sisi moralitas berbagai persoalan kemanusiaan. Selama ini, siswa hanya dicekoki ilmu teks buku dan menghamba kepada pelajaran teori-teori ilmu pasti.

Di sisi lain, waktu terus berkejaran dengan etika budaya baru dan aktivitas humanistik yang terus berkembang mengikuti kemajuan zaman. Dalam hal ini, sekolah lalai mengajarkan para siswa untuk menyelami realitas sosial yang bersifat massif. Akibatnya, siswa tidak lagi mempunyai moral dan terjebak kepada perilaku sadistik dan egoistik.

Sesungguhnya ada solusi sederhana yang mungkin bisa mengurangi dekadensi moral pelajar, diantaranya ialah sistem pendidikan di sekolah tidak lagi melulu menekankan prestasi 
akademik di atas kertas. Kembangkan dan tingkatkan pembinaan moralitas dan mentalitas para siswa dalam pergaulan sosial. Dalam lingkungan keluarga, para orang tua wajib menanamkan nilai dan norma sosial kepada anak. Orang tua harus terus-menerus melakukan pengawasan edukatif ketika anak menggunakan teknologi (ponsel dan internet). Untuk para pemimpin bangsa (tanpa kecuali), tunjukkan sikap dan perilaku santun kepada generasi penerus dalam memimpin negara.

Berikut kronologi penganiayaan HI terhadap sang guru yang disampaikan Budi:

1. Pada Kamis (1/2/2018) sekitar pukul 13.00, korban mengisi pelajaran seni melukis di halaman depan kelas XII. Semua siswa diberi tugas melukis. Pelaku tidak menghiraukan apa yang ditugaskan korban.

2. Korban kemudian menegur pelaku agar mengerjakan tugas seperti temannya yang lain. Teguran itu tetap tidak dihiraukan pelaku.

3. Karena teguran tidak dihiraukan, korban kemudian menggoreskan cat ke pipi pelaku.

4. Pelaku tidak terima dan mengeluarkan kalimat tidak sopan.

5. Karena tidak sopan, korban memukul pelaku dengan kertas absen.

6. Pukulan itu ditangkis pelaku dan langsung menghujamkan pukulan ke pelipis sebelah kanan korban. Akibatnya, korban tersungkur.

7. Murid yang lain melerai pelaku dan korban.

8. Korban bangun setelah terjatuh. Lengan kiri korban lecet karena menahan tubuhnya saat terjatuh.

9. Seusai kejadian tersebut, seluruh siswa masuk kelas. Di dalam kelas, pelaku sempat meminta maaf kepada korban disaksikan murid-murid yang lain.

10. Setelah pelajaran usai, korban dan pelaku pulang ke rumahnya masing-masing. Korban masih sempat bercerita kepada kepala sekolah tentang kejadian pemukulan yang dilakukan muridnya.

11. Setiba di rumah, korban langsung istirahat karena mengeluh pusing dan sakit kepala. Sekitar pukul 15.00, korban dibawa ke Puskesmas Jrengik, Kabupaten Sampang. Karena pihak Puskesmas tidak mampu menangani, korban kemudian dirujuk ke rumah sakit daerah Kabupaten Sampang. Korban kembali dirujuk ke rumah sakit DR Soetomo, Surabaya.

12. Pihak rumah sakit kemudian menangani korban dan korban dinyatakan mengalami mati batang otak (MBO), yang menyebabkan seluruh organ tubuhnya tidak berfungsi. Dokter memprediksi, korban tidak akan hidup lama.

13. Sekitar pukul 21.40, korban dinyatakan meninggal dunia. Korban kemudian langsung dibawa pulang ke rumahnya di Sampang. "Saya luruskan, tidak ada penghadangan korban 
oleh pelaku setelah jam pulang sekolah. Kejadian penganiayaan yang sebenarnya di depan halaman kelas," kata Budi. Ia berharap, tidak ada lagi informasi simpang siur mengenai peristiwa ini.

"Polres Sampang terus mendalami kasus ini dan pelaku sudah ditahan. (Jumat) malam ini (pelaku) sudah ditetapkan sebagai tersangka," ujarnya. Meski termasuk kategori di bawah umur, HI tetap dikenakan Pasal 351 Ayat 3 KUHP tentang Penganiayaan yang mengakibatkan matinya seseorang, dengan ancaman hukuman 7 tahun penjara. Di hampir semua kasus penganiyaan murid terhadap gurunya, umumnya di awali karena ketidak sukaan sang murid terhadap gurunya karena di tegur atau di beri sangsi, akibat tidak patuh terhadap guru. Kasus Penganiyaan Guru Budi di sampang Madura diawali dengan teguran sang guru terhadap muridnya, karena sang murid malas.

Secara umum hampir seluruh kalangan masyarakat merasa sedih dan prihatin atas kasus yang terjadi di Sampang, Madura. Secara garis besar, faktor pertama yang menyebabkan siswa melakukan aksi kekerasan kepada gurunya sendiri itu bersifat psikologis. Yang bersangkutan cenderung berkepribadian impulsif dan acap kali kesulitan mengendalikan emosi. Kondisi psikis ini melengkapi faktor sosialisasi dan subkultur kekerasan yang berkembang di habitat sosialnya. Harga diri yang terlalu tinggi dan ditambah kepribadian yang kurang matang dan kurangnya nilai moral yang diajarkan, sering menyebabkan seseorang tiba-tiba terpicu untuk melakukan aksi brutal dengan menganiaya figur guru yang seharusnya dihormatinya, meski karena hal sepele. Berbeda dengan siswa lain yang kebanyakan segan berbuat nakal dan tidak berani melawan gurunya, siswa yang memiliki kepribadian keras dan terbiasa tumbuh dalam lingkungan sosial yang familiar dengan kekerasan lebih berpeluang untuk melakukan tindak kekerasan dan menganiaya orang lain.

Faktor kedua, berkaitan dengan arah perkembangan iklim pembelajaran yang belakangan ini cenderung makin kompetitif, impersonal, dan kurang membuka kesadaran siswa tentang arti penting kohesi sosial, solidaritas, dan toleransi. Pendidikan karakter pelajaran tentang budi pekerti dan kaidah nilai moral sering kali tidak dikembangkan dengan serius. Hal ini terjadi karena banyak sekolah yang lebih mementingkan siswa sukses menempuh ujian nasional, kemudian dapat diterima di PTN terkenal sebagai representasi reputasi sekolah. Kasus bullying di beberapa sekolah yang dilakukan sejumlah siswa sempat menjadi viral di media sosial. Antara siswa satu dan siswa lain, yang seharusnya mengembangkan kegiatan bersama dan membangun keakraban, ternyata justru tega memplonco dan mengaiaya gara-gara hal sepele. Tidak sedikit pula siswa yang tega memalak 
temannya sendiri hanya karena ingin mendemonstrasikan bahwa ia lebih jagoan dan lebih berkuasa daripada teman-temannya yang lain.

Faktor ketiga adalah kurang dikembangkannya proses pembelajaran yang mampu menarik minat dan antusiasme siswa untuk terlibat aktif selama pelajaran berlangsung di kelas. Proses pembelajaran yang idealnya bersifat joyfull learning, sering malah berjalan menjemukan, dan bahkan menyubordinasi siswa. Akibatnya siswa kehilangan gairah terlibat dalam proses pembelajaran di kelas. Kehadiran guru-guru yang tidak mampu berkreasi dan mengembangkan metode pembelajaran yang menyenangkan bagi siswa, pada akhirnya menyebabkan aktivitas belajar di kelas menjadi kering dan tidak menarik bagi siswa. Di titik ini, jangan heran jika ada sebagian siswa yang membunuh kejenuhannya di kelas dengan berulah yang macam-macam--yang terkadang keluar dari batas-batas etika.

Guru adalah profesi yang mulia dan penuh dengan pengabdian. Meskipun di masyarakat telah tumbuh penghargaan dan penghormatan kepada guru, untuk memastikan agar para guru benar-benar terjamin keselamatannya dalam menjalankan pengabdian maka yang dibutuhkan adalah kepastian hukum dan kesadaran masyarakat. Kita semua sekarang sedang bersimpati kepada nasib malang guru di Sampang yang meninggal dalam menjalan tugas mulianya. Semoga momen ini menjadi renungan dan pelajaran bagi kita semua agar di kemudian hari tidak lagi ada guru yang menjadi korban peristiwa serupa.

Menurut saya masyarakat saat ini mengalami kehilangan sosok panutan. Sulit membedakan mana yang benar dan mana yang salah. Tontonan di media sangat mempengaruhi perilaku masyarakat. Para pemimpin, tokoh masyarakat, artis, bahkan para ulama banyak mempertontonkan adegan kekerasan baik secara lisan maupun secara fisik dihadapan publik, sikap permisif terhadap berbagai perilaku menyimpang membuat masyarakat, khususnya anak sulit untuk membedakan mana perilaku yang baik dan mana perilaku yang buruk. Maraknya kekerasan yang dilakukan murid dan orang tua terhadap gurunya, membuat beberapa sekolah mengantisipasinya dengan membuat perjanjian diatas materai dengan murid dan orang tua, terkait dengan berbagai kebijakan dan aturan sekolah khususnya dalam proses belajar mengajar. Jika murid dan orang tua setuju, silahkan putraputrinya studi di sekolahnya. Desakan agar pelaku penganiya guru dihukum seberat beratnya muncul dari berbagai pihak. Tapi dilubuk hati saya, "anak itu hanyalah korban dari situasi dan kondisi masyarakat yang buruk saja dimana budaya kekerasan sudah permisif !" , semoga kita dapat mengambil hikmahnya. 


\section{KESIMPULAN}

Berbagai kasus tindak kekerasan yang dialami guru di sejumlah daerah, seperti menjadi korban pemukulan orang tua siswa, menjadi korban intimidasi, perlakuan kasar dari berbagai pihak, juga kasus serupa lainnya, sangatlah penting menjadi perhatian. Para pihak yang berwenang dalam mengelola guru perlu segera menterjemahkan pasal-pasal dan peraturan yang lebih konkret tentang mekanisme perlindungan bagi pahlawan tanpa tanda jasa itu. Guru adalah profesi yang mulia dan penuh dengan pengabdian. Meskipun di masyarakat telah tumbuh penghargaan dan penghormatan kepada guru, untuk memastikan agar para guru benar-benar terjamin keselamatannya dalam menjalankan pengabdian maka yang dibutuhkan adalah kepastian hukum dan kesadaran masyarakat.

Menurut saya masyarakat saat ini mengalami kehilangan sosok panutan. Sulit membedakan mana yang benar dan mana yang salah. Tontonan di media sangat mempengaruhi perilaku masyarakat. Para pemimpin, tokoh masyarakat, artis, bahkan para ulama banyak mempertontonkan adegan kekerasan baik secara lisan maupun secara fisik dihadapan publik, sikap permisif terhadap berbagai perilaku menyimpang membuat masyarakat, khususnya anak sulit untuk membedakan mana perilaku yang baik dan mana perilaku yang buruk. Perbuatan manusiawi yang terjadi bisa saja dari beberapa factor nilai moral misalnya fakor hati nurani, secara fenomena dari realitas kehidupan bahwa manusia selalu melakukan pertimbangan-pertimbangan dalam hidupnya.

Misalnya manusia memiliki semacam pilihan untuk menegaskan pilihan-pilihan tersebut dan melakukan keputusan yang di pilihnya tersebut. Selain itu tindakan manusia juga menjadi factor bahwa manusia bertindak itu normal (sudah dengan sendirinya). Karena tindakan manusia tidak hanya berkaitan dengan eksistensinya sebagi makhluk hidup, melainkan juga mencetuskan nilai-nilai manusiawi. Kita semua bisa membahas secara panjang mengenai kejahatan manusia, tetapi titik tolak yang pasti ialah bahwa manusia memiliki kebebasan dan mampu merefleksi dari hati nurani yang benar, misalnya menggunakan akal budi secara sehat dan jernih, tujuan tindakan harus selalu masuk akal dan terarah kepada kebaikan, mampu bertanggung jawab atas tindakannya, selalu berfikir positif (kebaikan harus dilakukan dan keburukan harus dihindari). 


\section{DAFTAR PUSTAKA}

Dewantara, A. (2017). Filsafat Moral (Pergumulan Etis Keseharian Hidup Manusia).

Dewantara, W. A. (2017). filsafat Moral. Daerah Istimewa Yogyakarta: penerbit PT Kanisius. ISSBN, 978-979.

Dewantara, A. W. (2015). Filosofi Pendidikan yang Integral dan Humanis dalam Perspektif Mangunwijaya. JPAK: Jurnal Pendidikan Agama Katolik, 13(7), 3-9.

https://regional.kompas.com/read/2018/02/03/10041991/penganiayaan-guru-oleh-siswa-disampang-begini-kronologinya?page $=2$

https://www.cnnindonesia.com/nasional/20180202124909-12-273381/kronologi-siswaaniaya-guru-hingga-tewas-di-sampang

https://aladinalhafidz.blogspot.com/2017/07/makalah-sikap-sopan-terhadap-guru.html 